\title{
育児期にある夫婦関係の自覚と夫婦ペアレンティングへの思い
}

\section{Thoughts of spouses toward parenting together and consciousness of their marital relationship in the child-rearing stage}

\author{
清 水 嘉 子 (Yoshiko SHIMIZU)*
}

\section{抄 録}

目 的

育児期にある夫婦関係の自覚と実際的なかかわりの協働やその調整である夫婦ペアレンティングへの 思いを明らかにすることを目的に 7 組のカップル 14 名を対象として取り組んだ。

\section{研究方法}

家庭訪問による半構造化面接を夫婦別々に行い，夫と妻の語りを質的に分析し，コードから，サブカ テゴリー，カテゴリーを抽出した。

\section{結 果}

対象とした夫婦は，A県に在住しており，妻は平均 38.9 歳，夫は 41.1 歳であり，結婚して平均 8.7 年 が経過していた。妻は，〈子育ての中で感じる気持ちを大切にできる $><$ 成長している夫を感じる $>$ な どから【自分の子育てを支えているものがある】，＜子どもとのかかわりは間違っていない $><$ 自分の おかれた環境を自覚している>から【子どもへのかかわりへの思い】をもってく夫へのささやかな不満 がある ><夫とのコミュニケーションへの意識がある>から【夫に対する客観的な分析】をしなが

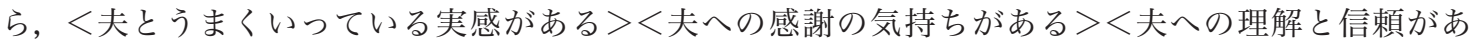
る>により【夫との協力関係への満足感】をもっていた。一方，夫はく夫婦の協力に対するスタンスが

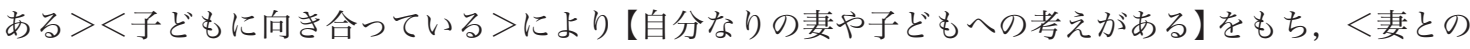
折り合いをつけている><妻と助け合うことはあたりまえ>などから【妻と助け合って子育てをするた

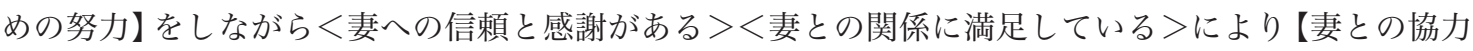
関係への満足感をもっていた。

\section{結 論}

夫婦は互いの信頼関係や感謝の心，支え合いの中で，二人の関係への満足感をもっていた。妻を支え たいという夫の思いと，子どものために，妻に支えられている実感の中で，二人の関係は保たれ調整さ れていた。こうした夫婦関係を基盤にして，良好な夫婦ペアレンティングへの思いが保たれていた。 キーワード：育児期，夫婦ペアレンティング，夫婦関係，語り

\footnotetext{
*名古屋学芸大学 (Nagoya University of Arts and Sciences)
} 


\begin{abstract}
Objective

We studied 14 people comprising 7 couples with the aim of clarifying spouses' consciousness of their marital relationship in the child-rearing stage and their thoughts on parenting together, which involves the interplay between their cooperative relationships and adjustments to these.

Methods
\end{abstract}

We conducted semi-structured interviews with husbands and wives separately during home visits, qualitatively analyzed their narratives, and extracted subcategories and categories from codes.

Results

The participating couples lived in A Prefecture. Mean ages of the wives and husbands were 38.9 and 41.1 years, respectively, and they had been married for a mean of 8.7 years. Wives held that [there is something supporting my child-rearing] from responses such as "I can appreciate the feelings I have during child-rearing" and "I feel my husband growing." They also had [thoughts on my involvement with my child] from responses such as "my involvement with my child is not wrong" and "I am conscious of the environment in which I am." While some conducted an [objective analysis of my husband] from responses such as "I am conscious of my communication with my husband," and "I have some minor complaints about my husband," some had [a sense of satisfaction toward the partnership with my husband] according to responses such as "I feel as if things are going well with my husband," "I have a sense of gratitude toward my husband," and "I have trust and understanding toward my husband." In contrast, husbands held that [I have my own ideas regarding my wife and child] according to responses such as "I have a stance on cooperation between spouses" and "I face my child." While some made [efforts to help my wife in child-rearing] according to responses such as "I make compromises with my wife," and "It's natural for my wife and I to help each other," some had [a sense of satisfaction toward the partnership with my wife] according to responses such as "I have trust and gratitude toward my wife" and "I am satisfied with the relationship with my wife."

Conclusion

Married couples who supported one another and had feelings of gratitude and a mutually trusting relationship also had a sense of satisfaction toward their relationship with one another. Relationships between husband and wife were maintained and adjusted through thoughts of husbands who indicated they wanted to support their wives and who in reality were also supported by their wives for the purposes of child-rearing. These marital relationships maintained favorable thoughts on parenting together.

Key words: child-rearing stage, parenting together, marital relationship, narratives

\section{I．緒言}

我が国は晚婚化と非婚化が進み，結婚後 5 年以内の 離婚率が高いと報告されている（厚生労働省，2016）。 結婚して 5 年以内の離婚が多いことについては，育児 期にある産後クライシスの問題として着目されており, 育児期の夫婦ペアレンティングを支援することは意義 があると考える。夫婦ペアレンティングは，両親が親 としての役割をどのように一緒に行うかということ (Feinberg, 2003）とされ，広義では，「その子どもの世 話と養育に責任を負うべき複数の養育者が共有する行 為」(McHale, 1997; McHale, et al. 1998) とされている。 出産後の夫婦関係では, 夫婦の関係が悪化したケース は $50 \%$, 変化のなかったケースは $30 \%$, 向上したケース は $20 \%$ となり，配偶者への愛情は半分のケースが $30 \%$ 減少し, 心理的な葛藤や摩擦が増えている。加えて,
夫婦のコミュニケーションも減少している (Belesky, et al. 1995)。同様に，夫婦の向き合いが出産後減少し， 母子の向き合いが有意に増加していた（佐々木他， 2007）。育児期をより良い体験にするために，結婚， 妊娠，出産，育児に向き合うカップルに，夫婦ペアレ ンティングを実践するための留意点など有意義な示唆 を示すことができると考える。子育ての多くの研究は 乳幼児期に集中しており，子どもの成長発達に伴い子 どもへの関りの質が変化する中で，妊娠，出産をどう 過ごすのかは，産後の子育てにおける親としての在り 方に影響すると考えられるが，我が国では，その支援 の多くが母親となっている。

母親の心身の縦断研究（清水，2017）では，母親の 育児の自信には父親に相談できることが影響してい た。どのように夫婦として共に子育てにあたつている のかという夫婦ペアレンティングの調整の実態とその 
プロセスの解明の取り組みは少ない中で（加藤他, 2012 /加藤他, 2014), 子育てを良好な夫婦ペアレン ティングの調整の中で行うことは，育児を次の親世代 に引き継ぐことができると考える。

そこで, 夫婦ペアレンティングの研究をスタートさ せ，妻と夫がお互いの子育ての批判をどのように受け 止め, その背景に何があると考えているのかアン ケート調査の記述から質的に分析した。この結果よ り，妻は批判されたことに対する受け止めはネガ ティブなものが見られ，夫婦関係の歪みとして認識し ていた。一方，夫は客観的に受け止め，それはそれと して聞いているものの, 自分の考えで行っているとこ ろが見られ，妻は夫である自分や，育児・家事に対す る不満があると受け止めており, 妻と夫の夫婦ペアレ ンティングの違いが明らかになった（清水，2020a）。 さらに，夫婦ペアレンティングにおける促進行動，批 判行動として，夫が子育てにかかわることに対して妻 が尊重，支持，激励する行動を促進行動とし，夫が子 ぞもに関わることに対して妻が拒否，避難，批判する 行動を批判行動とした上で促進行動と批判行動の夫婦 ペアレンティングの様相と関連要因を明らかにするこ とを目的とした研究に取り組んだ。促進行動と批判行 動の 4 パターン（促進高批判低，促進高批判高，促進 低批判低，促進低批判高）による量的な分析を行っ た。夫婦のペアレンティング調整の様相では 4 パ ターンの割合がほぼ同じ割合にみられ, 特に促進高批判低パターンの妻が，心理的に良い状態を示してい ることが明らかになった。このパターンでは夫への感 謝が高く，夫の支援のなさが低かった。さらに，育児 不安が低く, 話し合いをよく行い, 話し合いに対して 納得していた (清水，2020b)。

子育て期にある夫婦ペアレンティングの研究では, 母親による父親関与への抑制要因，すなわち父親に子 どもを任せられない状態 (gatekeeping)だけではなく, 促進要因の存在が指摘されている（加藤他，2012）。 妻の促進行動や批判行動の背景にある思いやその思い に関係していると考元られる夫婦関係の自覚を明らか にするために，今回7組14名のカップルに聞き取りを 行ったのでここに報告する。

\section{II. 研 究方法}

\section{1. 調査期間}

2019 年 5 月 7 月

\section{2. 調査方法}

2018 年 7 月に行われた $\mathrm{A}$ 県内の 3 歳から 4 歳の子ど もをもつ母親と父親を対象に保育園, 幼稚園, 子育て 支援センターを通じて行ったアンケート調査におい て，訪問による聞き取り調査への協力の意志を確認す るため, 調査用紙の返送時に協力の意志のある方に連 絡先 (住所)の明記を依頼した。後日, その連絡先に 調査の趣旨や方法について明記した資料を郵送し，返 送により協力の意思と連絡先 (電話) の明記を依頼し た。その後, 電話またはSNSで連絡を取り, 訪問の 具体的な日時や場所の調整をし, 家庭訪問による半構 造化面接を夫と妻と別に行った。相手の語りたい事柄 を丁寧に聞き取った。面接対象者への許可を得て テープによる録音を行った。

\section{3. 調査対象}

A 県内に在住する， 3 歳から 4 歳の子どもをもつご 夫婦で協力の意志のある 7 組 14 名を分析の対象とし た。この時期の子ぞもを持つ親は，子どものイヤイヤ 期や子どもとのコミュニケーションの難しさを抱えな がら, 子どもの成長を実感する時期にある。そして, ここまでの子育てに夫婦がどう過ごしてきたのか, 夫 婦関係の自覚や夫婦ペアレンティングへの思いに着目 した。

\section{4. 調査内容}

聞き取りの内容は, 夫婦関係の自覚として, 相手に 対する気持ちと変化, 夫婦関係への満足, 夫婦ペアレ ンティングへの思いとして，子育ての協力への考えと その根底にある思い, 協力の実態と満足, 協力を良好 なものにするための行動や言葉がけとその背景にある もの, 子育ての協力をするうえで大切なこと, 子育て の協力で阻害するもの, 子どもが増えたときの協力の 変化などであった。

\section{5. 分析方法}

半構造化面接で聞き取った語りを文字にし, 文字化 した記述内容を繰り返し読み込んでその状況を解釈し た。記述内容から, 研究目的に関係すると考元られる 夫婦関係の自覚と夫婦ペアレンテイングへの思いの語 りに，コード名をつけコーディングした。次に，カテ ゴリ化と概念化 (第 2 ・第3段階の抽象化) の段階に進 み，内容の似た者同士を並べて，まとまりをつくり， サブカテゴリ化した。さらにサブカテゴリを総括する 
名前をつけカテゴリを命名した。分析の全過程におい て，常に帰納的に検討し，コードとサブカテゴリ，サ ブカテゴリとカテゴリに矛盾がないことを確認しなが ら遂行した。分析の妥当性を保つため, 研究者の分析 後, 質的研究に精通する母性看護学教員 1 名に確認を 依頼し，両者が一致したものを採用した。変更が必要 なものは意見が一致するまで検討を行った。

\section{6. 倫理的配慮}

調査の依頼文には, 自由意思による協力であるこ と，聞き取りを行った後は個人が特定されないよう記 号化して処理し, デー夕を研究結果公表後破棄するこ とを明記した。倫理審査は名古屋学芸大学の倫理委員 会の審査を受け2018年に承認 $(\# 274)$ を得た後に研究 を開始した。

\section{III. 結果}

\section{1．対象となった夫婦の属性}

対象となった夫婦は，A県に在住し，妻平均 38.9 歳，夫 41.1 歳であり，結婚後平均 8.7 年であった。 14 名の面接時間は 46.9 分 \pm 9.0 (妻 46.1 分，夫 47.6 分) で あった。子どもは, 2.3 人であり, 妻は専業主婦 4 名, パートタイム 1 名, 育休中 1 名, フルタイム 1 名で あった。夫は全員フルタイムであった。核家族が 6 組，二世帯家族は 1 組であった (表 1 )。

7 組 14 名の夫婦関係や夫婦ペアレンティングについ て，妻と夫それぞれに‘'はコード，く>はサブカ
テゴリ,【】はカテゴリとして記述した。事例は夫AG，妻a-g と明記した。

\section{2. 妻の夫婦関係の自覚と夫婦ペアレンティングへの 思い}

夫婦ペアレンティングへの思いとしで苦しかった 自分が娘と分かり合えたことで楽になったc' ‘お店を しているので子ぞもには惄しい思いもあるかもしれな いf'などからく子育ての中で感じる気持ちを大切にで きる>ことがあった。また，“夫に育児に協力しても らうために自分なりに誘導しているb’ ‘尒もの勉強 をよく見ているので自分が主導権をもっているd'など から<夫婦関係に裏打ちされたコントロールカがあ る>があった。さらに，“夫を頼りにして尊敬してい る $\mathrm{e}$ “潔癖主義でせっかちな自分に対して夫はそのこ とをわかって対応してくれているg’な゙によりく支え てくれる夫の存在がある>ことを感じながら，“夫は 少しずつ言わなくてもやれるようになってきている d' “夫に自分が育てられていることを感じているb’ ‘下の 子ができてさらに協力的になったf'などによりく成長 している夫を感じる>ことがあった。また, ‘ママ友 は頼りになる存在a' “一人目は大変だけど大きくなる と助けてくれるようになったd'などからく夫の家族や ママ友・子どもの支えがある>ことを感じながら， 【自分の子育てを支えているものがある】という気持 ちがあった。さらに，“上の子の育ちを見て今の子育 てでいいんだと思えるb' ‘育てで大切にしているこ とは自然に触れること d'などによりく子どもとのかか

表1 対象者の属性

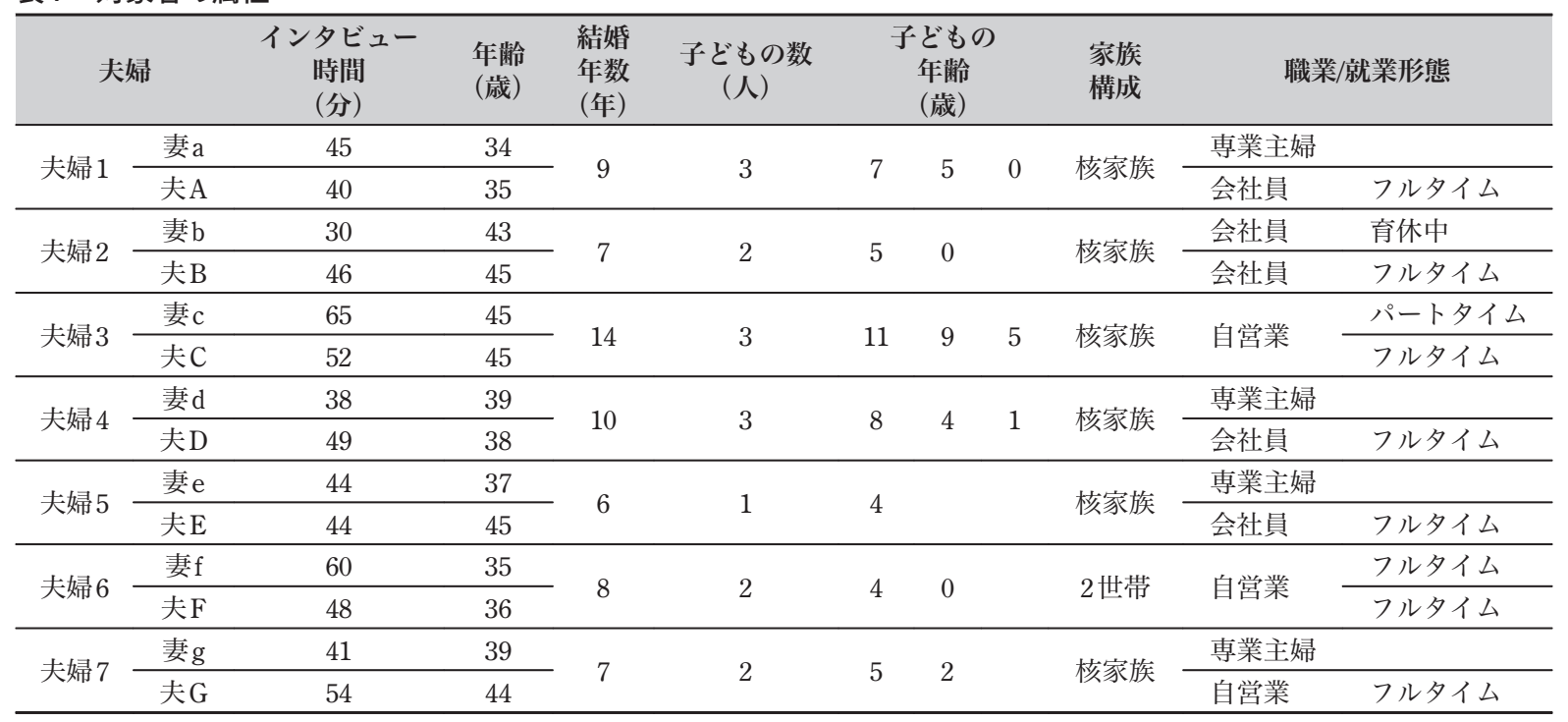


わりは間違っていない>と信じていた。この先何が あるか分からないからお互いの子育ての価值観に折り 合いをつけているb’ ‘両親のことは夫もつらいはずc’ などからく自分のおかれた環境を自覚している>こと も加わり，【子どもへのかかわりへの思い】があった。 そして，“父親にしかできない子育てをもっとしてほ しいb’ ‘自分の子育てを否定されている感じc’などに より<夫へのささやかな不満がある>を抱いていた。 一方で, ‘夫の帰りが遅いことは気になっているが嫌 がりそうなことは言わないa’ ‘余裕ができたら喧嘩も しなくなりこんなもんだと思えるようになったgなど によりく夫とのコミュニケーションへの意識があ る>と意識することで,【夫に対する客観的な分析】を していた。その上で，“夫は子どもとうまくやってい るので心配ないa’ ‘お互いに思いやっていることを自 覚しているf'などによりく夫とうまくいっている実感 がある>があった。そして，“言わなくても子どもを 見てくれている夫に感謝の言葉を伝えている $\mathrm{e}^{\mathrm{a}}$ '自分 や子どもに献身的に尽くしてくれる夫に感謝している g’などにより<夫への感謝の気持ちがある $>$ 感謝の 思いを抱いていた。さらに，“夫と子育てに対する考 えが一致しているのでイライラした気持ちを話すこと ができる $\mathrm{e}$ ‘自分の親に対する気遣いがある $\mathrm{f}$ などに より<夫への理解と信頼がある>と感じながら，【夫 との協力関係への満足感】を抱いていた。

妻は，夫婦ペアレンティングへの思いとして【自分 の子育てを支えているものがある】により【子どもへ のかかわりへの思い】をもって【夫に対する客観的な 分析】をしながら【夫との協力関係への満足感】によ る夫婦関係の自覚があった (表2)。

\section{3. 夫の夫婦関係の自覚と夫婦ペアレンティングへの 思い}

夫婦ペアレンティングへの思いとして‘子育てを分 担する考え方は良くない $\mathrm{A}$ ’ ‘親の影響を受けている自 分がいるC’などによりく夫婦の協力に対するスタン スがある>と自分なりの立ち位置を認識していた。さ らに, ‘子どもの責任は両親 C’ 勉強ばかりではだめ 息抜きを子どもにはさせたい D’などによりく子ども に向き合っている>と感じながら【自分なりの妻や子 どもへの考えがある】と認識していた。そして, ‘子ど もが増えて良かった F’ “二人で出かけなくなり子ども 中心の生活になっている G'などによりく子育てを通 した変化への気づきがある>ことで，‘堉ての考元
に違いはあるが落ち着いて興奮せずに妻に接していく C’ ‘手伝いたい気持ちと休みたい気持ちのバランスを とつているD’などにより, <妻との折り合いをつけ ている>と妻との関係を保つための調整をしていた。

その上で, ‘子どもがいるんだから違いを認め合わ なければならないC’ ‘自分の子どもだから自分も手伝 う F’などにより，〈妻と助け合うことはあたりま え>と考えていた。加えて, “妻の頑張りに答えたい 気持ちがある B' ‘子どもが増えて妻の大変な姿を見て 手伝いたい D’などの思いにより<妻の気持ちがわか るから応えたい>という気持ちがあった。そして‘妻 を立てているが偉そうにしない $\mathrm{B}$ ' ‘妻は認められてい ない思いがあるので言い過ぎないようにしているC' などにより，＜妻を支えながらうまくやっていきた い>と考えながら,【妻と助け合って子育てをするた めの努力】をしていた。

さらに, 夫婦関係への自覚として, “余裕がなくな ると子どもにあたるが妻がかばってくれる F’ “家事も 育児もちゃんとしており不満はなくありがたいという 気持ちをもっている G’などの思いから<妻への信頼 と感謝がある>を抱いていた。そしてさらに, “妻を 頼りにしている自分がいるA' “妻には特に求めること はないF’などの思いから<妻との関係に満足してい る>と感じており,【妻との協力関係への満足感】を抱 いていた。夫は夫婦ペアレンティングへの思いとし て、【自分なりの妻や子どもへの考えがある】をもち， 【妻と助け合って子育てをするための努力】をしなが ら, 夫婦関係の自覚として,【妻との協力関係への満 足感】があった (表3)。

\section{IV. 考察}

\section{1. 夫婦関係の自覚と夫婦ペアレンティングへの思い}

夫婦ペアレンティングを良好に発揮するための夫婦 関係は, 妻の【夫との協力関係への満足感】と, 夫の 【妻との協力関係への満足感】により, 夫婦の信頼関係 が維持され, お互いへの感謝や夫婦関係への満足感に よる夫婦関係の自覚があった。そして,【自分の子育て を支えているものがある】こと，【子どもへのかかわり への思い】妻と助けあって子育てをするための努力】 することによって，二人の子育てや今の子育てへの自 信や支えられている実感により, 夫婦の協力関係は保 たれていた。また，〈妻と支えあうことはあたりま え>, <妻の気持ちがわかるから応えたい >, <妻を 
表2 妻の夫婦関係の自覚と夫婦ペアレンティングへの思い

\begin{tabular}{|c|c|c|}
\hline カテゴリー & サブカテゴリー & コード \\
\hline \multirow{3}{*}{$\begin{array}{l}\text { 夫との協力関係への } \\
\text { 満足感 }\end{array}$} & 夫とうまくいっている実感がある & $\begin{array}{l}\text { 夫の育ちから夫の人柄がわかる } \mathrm{a} \text { 言ったことに答えてくれる分夫はサポー } \\
\text { ト者と思う } \mathrm{a} \text { 夫は子どもとうまくやっているので心配ない } \mathrm{a} \text { 日常生活でも } \\
\text { 夫の判断や意見に従う e お互いに思いやっているこを自覚している } \\
\text { いやりや思仕の気持ちをお互いに持っているからうまくやれているg }\end{array}$ \\
\hline & 夫への感謝の気持ちがある & $\begin{array}{l}\text { 好きで結婚した相手だし自分を大事にしてくれてありがたい d ありがとう } \\
\text { はよく言うょうにしているd 言わなくても子どもを見てくれている夫に感 } \\
\text { 謝の言葉を伝えている } \mathrm{e} \text { 自分や子どもに献身的に尽くしてくれる夫に感謝 } \\
\text { しているg }\end{array}$ \\
\hline & 夫への理解と信頼がある & 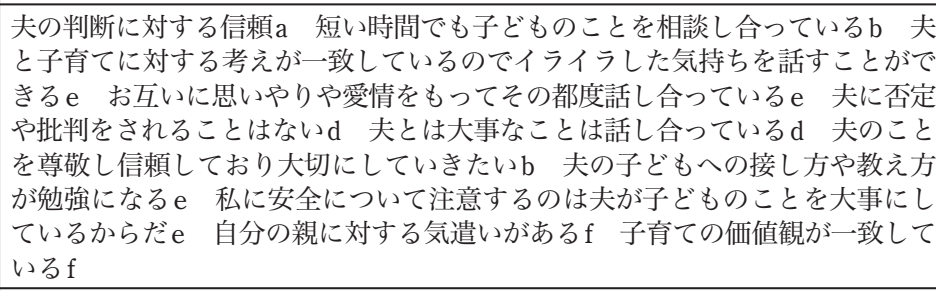 \\
\hline \multirow{5}{*}{$\begin{array}{l}\text { 自分の子育てを支え } \\
\text { ているものがある }\end{array}$} & $\begin{array}{l}\text { 子育ての中で感じる気持ちを大切 } \\
\text { にできる }\end{array}$ & $\begin{array}{l}\text { 子育てで感じるポジティブな気持ちを子どもにも伝えていきたい } \mathrm{b} \text { 苦し } \\
\text { かった自分が娘と分かり合えたことで楽になった } \mathrm{c} \text { 掂をしているので } \\
\text { どもには寂しい思いもあるかもしれないf }\end{array}$ \\
\hline & $\begin{array}{l}\text { 夫婦関係に裏打ちされたコント } \\
\text { ロールガある }\end{array}$ & 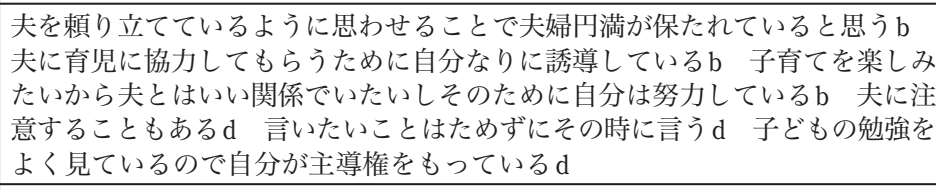 \\
\hline & 支えてくれている夫の存在がある & 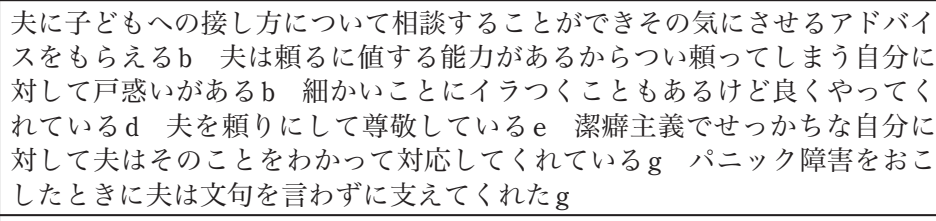 \\
\hline & 成長している夫を感じる & $\begin{array}{l}\text { 夫は少しずつ言わなくてもやれるようになってきている } \mathrm{d} \text { 夫に自分が育て } \\
\text { られていること感じている } \mathrm{b} \text { 下の子ができてさらに協力的になった } \\
\text { は仕事が好きでよく働き自分と出会ってからは話すようなり角がとれた } \mathrm{g}\end{array}$ \\
\hline & $\begin{array}{l}\text { 夫の家族やママ友・子どもの支え } \\
\text { がある }\end{array}$ & $\begin{array}{l}\text { ママ友は頼りになる存在 } \mathrm{a} \text { 夫は土日は休みたいようなので家のことは子ども } \\
\text { たちにお願いしている } \\
\text { 人目は大変だけど大きくな働くか家にいるか好きにしていいと義母は言う } \mathrm{a} \text { - } \\
\end{array}$ \\
\hline \multirow[t]{2}{*}{$\begin{array}{l}\text { 夫に対する客観的な } \\
\text { 分析 }\end{array}$} & 夫へのささやかな不満がある & 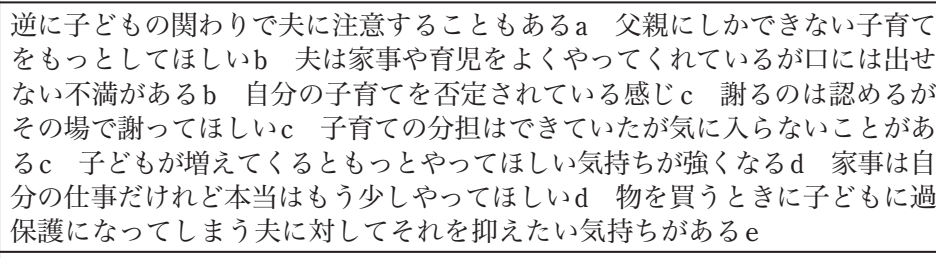 \\
\hline & $\begin{array}{l}\text { 夫とのコミュニケーションへの意 } \\
\text { 識がある }\end{array}$ & 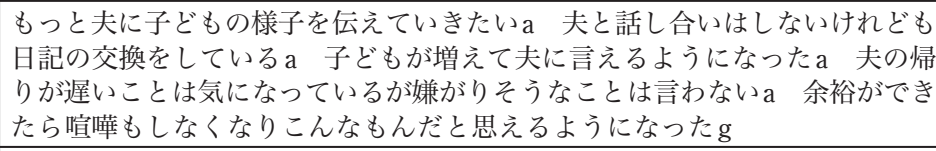 \\
\hline \multirow[b]{2}{*}{$\begin{array}{l}\text { 子どもへのかかわり } \\
\text { への思い }\end{array}$} & $\begin{array}{l}\text { 子どもとのかかわりは間違ってい } \\
\text { ない }\end{array}$ & $\begin{array}{l}\text { 上の子の育ちを見て今の子育てでいいんだと思えるb 子育てで大切にして } \\
\text { いることは自然に触れることd 子どもの気持ちを大切にしたいので親だけ } \\
\text { では決めない }\end{array}$ \\
\hline & 自分のおかれた環境を自覚している & 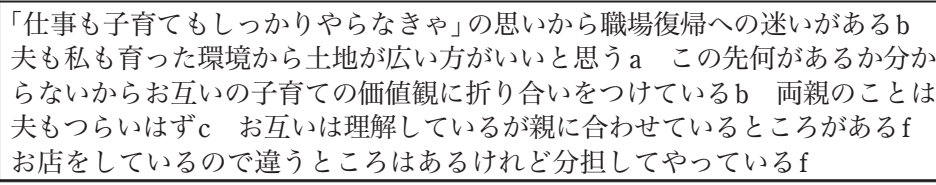 \\
\hline
\end{tabular}

支えながらうまくやっていきたい>など，他の人に支 えられている感覚や自らが感じる幸福感を大切にする
などの夫婦ペアレンティングへの思いがあった。

夫婦間における共感的なかかわりによって，夫婦， 
表3 夫の夫婦関係の自覚と夫婦ペアレンティングへの思い

\begin{tabular}{|c|c|c|}
\hline カテゴリー & サブカテゴリー & コード \\
\hline \multirow[t]{2}{*}{$\begin{array}{l}\text { 妻との協力関係への } \\
\text { 満足感 }\end{array}$} & 妻への信頼と感謝がある & 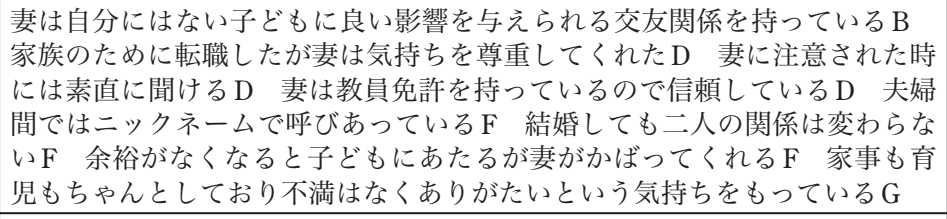 \\
\hline & 妻との関係に満足している & 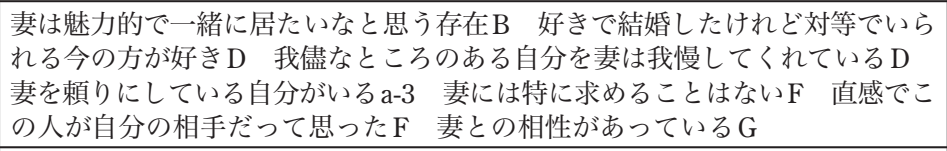 \\
\hline \multirow{2}{*}{$\begin{array}{l}\text { 自分なりの妻や子ど } \\
\text { もの考えがある }\end{array}$} & $\begin{array}{l}\text { 夫婦の協力に対するスタンスがあ } \\
\text { る }\end{array}$ & 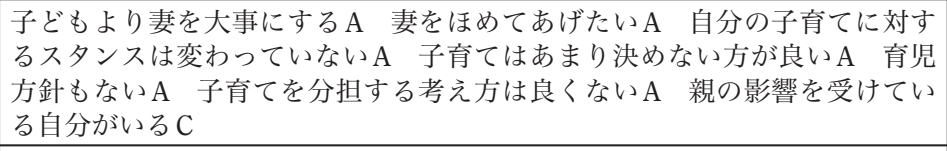 \\
\hline & 子どもに向き合っている & $\begin{array}{l}\text { 子どもへの関りをどうす扎良かつたのかいつも考えているC 子どもの気 } \\
\text { 持ちが大切だと思う C 子どもの責任は両親 C 勉強ばかりではだめ息抜き } \\
\text { を子どもにはさせたい D 自分で判断して行動できる人に育てたい } \\
\text { もの気持ちを聞いたりスキンシップしながら大切なことは伝えたい } \mathrm{G} \\
\end{array}$ \\
\hline \multirow{5}{*}{$\begin{array}{l}\text { 妻と助け合って子育 } \\
\text { てをするための努力 }\end{array}$} & $\begin{array}{l}\text { 子育てを通した変化への気づきが } \\
\text { ある }\end{array}$ & 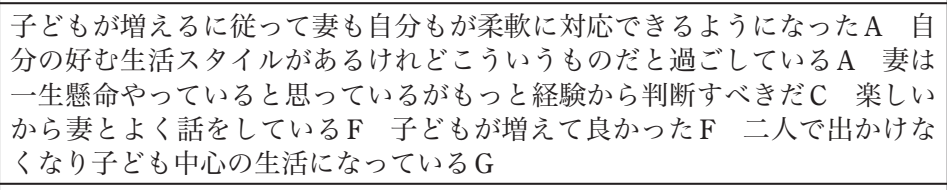 \\
\hline & 妻との折り合いをつけている & 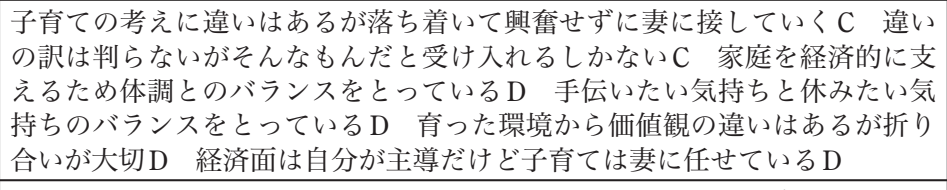 \\
\hline & 妻と助け合うことはあたりまえ & 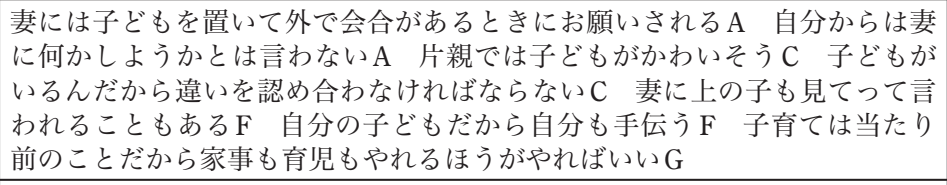 \\
\hline & 妻の気持ちがわかるから応えたい & $\begin{array}{l}\text { 自分が怒るときは妻に申し訳なく思う } \mathrm{A} \text { 妻の頑張りに答えたい気持ちがあ } \\
\text { る } \mathrm{B} \text { 答えのないことが多い中で心と体のバランスが大切 C 子どものこと } \\
\text { は何でも話し合い子どもを見ている妻の意見を尊重する } \mathrm{D} \text { 折り合いの中で } \\
\text { 可能な限り妻を手伝いたい } \mathrm{D} \text { 子どもか増えて妻の大変な姿を見て手伝いた } \\
\text { い } \mathrm{D} \text { 子どもの話はよく聞いてやりたい } \\
\end{array}$ \\
\hline & $\begin{array}{l}\text { 妻を支えながらうまくやっていき } \\
\text { たい }\end{array}$ & $\begin{array}{l}\text { 何かあったらいけないので子どもよりは遅く寝る } \mathrm{A} \text { 妻と考え方に違いはある } \\
\text { がイライラする感じもなく不満もない } \mathrm{B} \text { 妻を立てているが偉そうにしない } \\
\mathrm{B} \text { 妻は認められていない思いがあるので言い過ぎないようにしているC 夫 } \\
\text { 婦が同じ方向を見ていることが大事 } \mathrm{F} \text { 妻との会話からいろんなことがわかる } \\
\text { ので会話を大事にしたい } \mathrm{G} \text { 妻や子どものことが気になるので電話をする } \mathrm{G}\end{array}$ \\
\hline
\end{tabular}

特に妻の関係満足度を高め, 関係性を維持しているの ではないか (神谷，2013）と言われているように，夫 婦が互いを理解し合うことは，互いの関係満足度に影 響していることが本結果からも伺える。つまり，妻の 【夫との協力関係への満足感】として<夫への感謝の

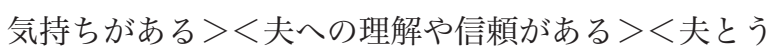
まくいっている実感がある>や，夫の【妻との協力関 係への満足感は】として<妻への信頼と感謝があ る $><$ 妻との関係に満足している $>$ に現れている。そ して，互いに支え合い，育ち合っているという夫婦関
係の自覚は, 妻の夫婦関係に裏打ちされたコント ロール力や, 夫の妻の気持ちに答えたい, 助け合うこ とは当たり前などの考えや自分なりの柔軟さやバラン ス，うまくやりたい気持ちや，妻に支えられている子 育ての実感による夫婦ペアレンティングへの思いによ り，妻主導の中で夫がそれに対して柔軟に対応してい ることがわかる。妻から夫に伝えるスキルが高いほど 夫からのサポートが受けやすいと述べており（佐藤, 2012), 本結果からも,「妻の夫を立てているように思 わせることで・・」のコードにあるように，妻は夫を 
尊重する気持ちから夫を立てながら，一方で「夫に育 児に協力してもらうために自分なりに誘導している」 のコードからも，夫を自分の考える方向にコント ロールしている妻の調整力が大きいことが分かる。そ れに加えて，夫の妻を立てる気持ちやうまくやりたい 思いが夫婦ペアレンティングの根底にあると考えられ た。

結婚生活の経過による夫婦満足度は, 結婚年数が増 えるに従ってハネムーン効果が薄れ低下している(永 井，2005）。そのため, 未就学児がいるカップルで妻 の夫婦関係満足度が低いことから家族役割に関する看 護者や周囲のサポート者からの説明や支援が必要にな る。3歳の子どもを持つ母親が抱く夫の協力が減つた と感じていると先行研究 (清水, 2017) による量研究か ら明らかにされているが，今回の結果では，むしろ夫 婦の信頼関係を育んでいる姿があることに加えて, 子 ぞもが大きくなるに従い, 夫とのかかわりが変化して いることに気付いていることが質的な聞き取りから明 らかとなった。本研究から，そうした変化は，夫婦関 係への満足感が根底にあることによって, 夫婦ペアレ ンティングへの良い調整がなされていると考えられる。

妊娠期の夫婦関係意識に関する因子分析からも良好 な人間関係や夫の支援・信頼，パートナーの受容の因 子項目が抽出されており，夫婦関係を調整する上で大 切な要素であることが示されている（伊藤，2015）。 本結果においてく夫とうまくいっている実感 $><夫 へ ~$ の感謝の気持ちがある $><夫 へ の$ 理解と信頼があ る>ことから，良好な人間関係や夫の支援・信頼, パートナーの受容に類似する結果が示されていた。ま た, 子どもができ, 第一子誕生後には, 夫婦共通の目 標への歩みの開始や, 育児の大切さを理解し妻をサ ポートする役割の追加，そして夫婦関係のバランスを 保つための工夫や再調整の実施，親になるお互いを受 け入れようとする姿勢の出現, 責任感の芽生えによる 家族意識の向上など夫から見た夫婦の変化が報告され ている(荒川他，2012）。つまり，夫婦ペアレンティ ングでは, 子どもが増え様々な困難を乗り越える中 で，お互いが大切にしている思いや考えに支えられた 互いの育ち合いや理解し合い, そして支え合いの姿と 感謝の心によって，二人の関係への満足感が保たれて いると考えられた。調査対象者の中には夫をコント ロールしている妻の調整力が生まれ，夫もそのことを 受け入れながらバランスをとつていた。母親による父 親関与への抑制要因, すなわち父親に子どもを任せら
れない状態 (gatekeeping) だけではなく, 促進要因の 存在が指摘されている (加藤他, 2012)。本研究にお いては，母親の gatekeepingに関する語りは見られず, むしろ促進要因としての゙ありがとうはよく言うよう にしているd’や‘言わなくても子どもを見てくれてい る夫に感謝の言葉を伝えている $\mathrm{e}^{2}$ な゙の感謝を言葉に している行動や, ‘夫に育児に協力してもらうために 自分なりに誘導しているb’などの，夫を子育てに引き 込もうとする具体的な行動や，“夫を頼り立てている ように思わせることで夫婦円満が保たれていると思う b’などの夫婦関係を保つための具体的な行動があつ た。

妻の【夫に対する客観的な分析】では，〈夫へのさ

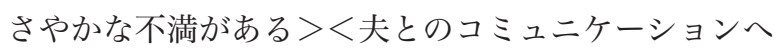
の意識がある>の自覚は, 妻の中で夫との関係性をプ ラスの方向に向かわせるための自身の中に湧いてくる 不満や気づきでもあった。夫婦関係がうまくいってい るという自覚は, 夫婦ペアレンティングに良い影響を もたらしており,このうまくいっている自覚がもてな いことは，プラスの方向に向かえない，閉鎖的な関係 性が起こりうる。つまり, 結婚して 5 年以内の離婚が 多い(厚生労働省, 2016) ことについては, 育児期に ある産後クライシスの問題として発展していくことが 考元られる。

\section{2. 夫婦ペアレンティングを良好なものとする支援}

結婚生活におけるコミットメント志向性モデルによ ると, 危機をきっかけに潜んでいた不満が表面化し, 制度維持レベルの結婚生活を続けたいレベルに留ま り, 人生の主要な節目である子育て期に, これまでど のような関係性を築いていたのかが問わ机ることにな る (宇都宮, 2020)。夫婦関係の質において, 夫婦関 係満足度の高いケースには, 互いに表出コミュニ ケーションが多く, 夫への信頼が高く, 役割としての 関係よりも個人としての関係について信頼が高いこと が示されている (田中，2016)。本結果においても， まずは夫婦としての互いの信頼や感謝の気持ちに支え られた夫婦関係への満足感が示されている。

また，子育ては夫婦でシェアする，共同して養育す る考え方が海外ではある中で, 日本では性別役割分業 の考えが根強くよくあることから, 日本の夫婦にコペ アレンティングがうまく機能しないと述べられている が (江崎グリコ, 2020), 今回の調査においては, 性 役割分業というょりは，互いの信頼関係や感謝の心， 
支え合い，理解し合い，育ち合いの中で，二人の関係 への満足感をもつていた。妻を支えたいという夫の思 いと，子どものために，妻に支えられている実感の中 で，二人の関係は保たれ調整されていることが分 かった。

子育て期の妻は，会話時間と自己開示が関係満足度 を大きく規定しているが，夫は，自己開示は妻ほど関 係満足度に規定されず，妻の夫への開示が夫の関係満 足度を規定していた。つまり夫は，子育て期において は会話時間が関係満足を規定していた（伊藤他, 2007)。このことからも，本結果から見えてきたこと を夫婦への支援として生かしていくとするならば，特 に夫婦ペアレンティングを良好なものとするために， 二人の関係を良いものとするために，コミュニケー ションをとること，その中で特に妻は自己開示できる ことが大切である。また，夫婦ペアレンティングが保 たれている場合は，すでに夫婦の間で互いの調整力が 発揮されバランスをとつていることが明らかなことか ら，夫婦ペアレンティングについて語ってもらい，そ れを支えていると考えられることについて支持するこ とにより，夫婦ペアレンティングにおける望ましい行 動が強化されるのではないかと考える。

\section{V. 結 論}

育児期にある 7 組のカップル 14 人からの聞き取りを 行った結果，夫婦ペアレンティングを良好に発揮する ための夫婦関係は，妻の【夫との協力関係への満足 感】と, 夫の【妻との協力関係への満足感】により, 夫婦の信頼関係が維持され，お互いへの感謝や夫婦関 係への満足感による夫婦関係の自覚があった。そし て，【自分の子育てを支えているものがある】こと， 【子どもへのかかわりへの思い】妻と助けあって子育 てをするための努力】することよって，二人の子育て や今の子育てへの自信や支えられている実感により, 夫婦の協力関係は保たれていた。また，〈妻と支えあ うことはあたりまえ>，〈妻の気持ちがわかるから応 えたい〉，〈妻を支えながらうまくやっていきた い>など，他の人に支えられている感覚や自らが感じ る幸福感を大切にするなどの夫婦ペアレンティングへ の思いがあった。

\section{謝 辞}

本研究において, 調査に協力くださいました協力施
設，対象者の皆様に感謝いたします。また，家庭訪問 による聞き取りを共に行った母性看護学分野の 2 人の 教員に心より感謝します。なお本研究は，2017～2020 年文部科学省補助金 基盤研究 C 家族の再構築を促 す子育て支援プランの検討 (課題番号17K12304)の一 部になる。

\section{利益相反}

本論文内容に関連する利益相反事項はない。

\section{文 献}

荒川恵美子，西村昭徳，菊池春樹他 (2017). 未就学の子 ぞもを持つ夫婦の関係調整に関する我が国の研究動 向. 東京成徳大学臨床心理学研究，17，188-197.

Belesky, J. \& Kelly, J. (1994)／安次嶺佳子訳 (1995). The Transition to Parenthood子供を持つと夫婦に何が起こ るか。草思社，東京，10-60，133-167。

江崎グリコ株式会社。＜日本・フィンランド「Coparenting コペアレンティング」比較妊娠期・育児期の夫婦間意 識調査>妊娠期からの夫婦の密なコミュニケーショ ンが，育児期の産後うつや育児ストレス軽減に子ど もへの愛情や笑顔のあふれる過程につながる 「Coparenting」社会を実現. http://www.atpress.ne.jp/ news/176629 (アクセス2020.1.16)

Feinberg, M. (2003). The internal Structure and ecological context of coparenting. A framework for research and intervention. Parenting: Science and Practice, 12, 1-21.

伊藤裕子 (2015)。 夫婦関係における親密性の様相。発達 心理学研究, 26(4), 279-287.

伊藤裕子, 相良順子, 池田政子 (2007)。 夫婦のコミュニ ケーションが関係満足度に及ぼす影響一自己開示を 中心に一。文教学院人間学部研究紀要，9(1)，1-15. 神谷哲司 (2013)。育児期夫婦ペアデータによる家庭内役 割タイプの検討 役割観の異動類型化と夫婦の関係 性の視点から。発達心理学研究, 24, 238-249.

加藤道代，黒澤泰，神谷哲司 (2012)。母親の gatekeeping に関する研究動向と課題一夫婦ペアレンティングの 理解のために。東北大学院教育学研究科研究年報, 61(1), 09-126.

加藤道代，黒澤泰，神谷哲司 (2014)，夫婦ペアレンティ ング調整尺度作成と子育て時期による変化の横断的 検討. 心理学研究, 84(6), 566-575.

厚生労働省 : 平成 28 年度ひとり親世帯等調查結果報告, ひとり親になった時の親及び末子の年齢.https:// 
www.mhlw.go.jp/file/06-Seisakujouhou-11920000-

Kodomokateikyoku/0000188152.pdf (アクセス 2020.8.5)

McHale, J.P. (1997). Overt and covert coparenting processes in the family. Family process, 36, 183-201, 15.

McHale, J.P. \& Rasmussen, J.L. (1998). Coparental and family group-level dynamics during infancy: Early family precursors of child and family functioning during preschool. Deveropement and Psychopathology, 10, 39-59.

永井暁子 (2005)。結婚生活の経過による妻の夫婦関係満足 度の変化. 季刊家計経済研究, SPRING，66，76-81。 佐々木裕子，高橋真理 (2007). 父親から見た第一子出生 前後における夫婦関係の評価一家族イメージ法によ る分析を中心に一。家族看護研究，13(1)，53-59.

佐藤小織 (2012)。初産婦の夫婦関係の評価と育児満足感を
構成する諸要因の関係に関する研究 育児初期の核家 族に焦点をあてて。 日本助産学会誌，26，222-231. 清水嘉子 (2017)。乳幼児の母親の心身の状態に関する縦 断研究. 日本助産学会誌, 31(2), 120-129.

清水嘉子 (2020a)。育児期にある夫婦ペアレンティングー 互いの育児の批判をめぐって一。 日本助産学会誌, $34(1), 103-113$

清水嘉子 (2020b)。堉て期にある夫婦ペアレンティング調 整パターンと関連要因。母性衛生，61(2)，340-351. 田中慶子 (2016). 家族形成期の夫婦関係の「質」とその後の 評価。季刊家計経済研究, AUTUMN, 112, 33-45. 宇都宮博. 結婚生活の長期化と夫の幸せ妻の幸せ, RADIANT, 1, 12-5, 12, http://www.ritsumei.ac.jp/ research/radiant/heart/story2.html (アクセス 2020.1.16) 